\title{
Biogenic nitrogen gas production at the oxic-anoxic interface in the Cariaco Basin, Venezuela
}

\author{
E. Montes ${ }^{1}$, M. A. Altabet ${ }^{2}$, F. E. Muller-Karger ${ }^{1}$, M. I. Scranton ${ }^{3}$, R. C. Thunell ${ }^{4}$, C. Benitez-Nelson ${ }^{4}$, L. Lorenzoni ${ }^{1}$, \\ and Y. M. Astor ${ }^{5}$ \\ ${ }^{1}$ College of Marine Science, University of South Florida, St. Petersburg, Florida, USA \\ ${ }^{2}$ School of Marine Science and Technology, University of Massachusetts Dartmouth, New Bedford, Massachusetts, USA \\ ${ }^{3}$ School of Marine and Atmospheric Science, Stony Brook University, Stony Brook, New York, USA \\ ${ }^{4}$ Marine Science Program \& Department of Earth and Ocean Sciences, University of South Carolina, Columbia, \\ South Carolina 29208, USA \\ ${ }^{5}$ Estación de Investigaciones Marinas de Margarita, Fundación La Salle de Ciencias Naturales, Apartado 144, Porlamar, \\ Estado Nueva Esparta, Venezuela
}

Correspondence to: E. Montes (emontesh@mail.usf.edu)

Received: 16 July 2012 - Published in Biogeosciences Discuss.: 8 August 2012

Revised: 3 December 2012 - Accepted: 17 December 2012 - Published: 17 January 2013

\begin{abstract}
Excess nitrogen gas $\left(\mathrm{N}_{2}^{\mathrm{xs}}\right)$ was measured in samples collected at six locations in the eastern and western sub-basins of the Cariaco Basin, Venezuela, in September 2008 (non-upwelling conditions) and March 2009 (upwelling conditions). During both sampling periods, $\mathrm{N}_{2}^{\mathrm{xs}}$ concentrations were below detection in surface waters, increasing to $\sim 22 \mu \mathrm{mol} \mathrm{N} \mathrm{kg}{ }^{-1}$ at the oxic-anoxic interface $\left(\left[\mathrm{O}_{2}\right]<\sim 4 \mu \mathrm{mol} \mathrm{kg}^{-1}, \sim 250 \mathrm{~m}\right)$. Below the oxicanoxic interface $(300-400 \mathrm{~m})$, the average concentration of $\mathrm{N}_{2}^{\mathrm{xs}}$ was $24.7 \pm 1.9 \mu \mathrm{mol} \mathrm{N} \mathrm{kg}^{-1}$ in September 2008 and $27.5 \pm 2.0 \mu \mathrm{mol} \mathrm{N} \mathrm{kg}^{-1}$ in March 2009, i.e., $\mathrm{N}_{2}^{\mathrm{xs}}$ concentrations within this depth interval were $\sim 3 \mu \mathrm{mol} \mathrm{N} \mathrm{kg}{ }^{-1}$ higher $(p<0.001)$ during the upwelling season compared to the non-upwelling period. These results suggest that $\mathrm{N}$ loss in the Cariaco Basin may vary seasonally in response to changes in the flux of sinking particulate organic matter. We attribute the increase in $\mathrm{N}_{2}^{\mathrm{xS}}$ concentrations, or N-loss, observed during upwelling to: (1) higher availability of fixed nitrogen derived from suspended and sinking particles at the oxic-anoxic interface and/or (2) enhanced ventilation at the oxic-anoxic interface during upwelling.
\end{abstract}

\section{Introduction}

Dissolved inorganic nitrogen (DIN or "fixed" nitrogen), includes nitrate, nitrite, and ammonium. This nutrient often limits primary production in marine systems (Codispoti, 1989; Smith, 1984) and thus plays a role in the modulation of climate (Altabet et al., 2002; Falkowski, 1997; Ganeshram et al., 2000; Gruber, 2004). In the ocean, new DIN is primarily derived from nitrogen fixation $\left(\mathrm{N}_{2} \rightarrow \mathrm{NH}_{4}^{+}\right)$ by microbial diazotrophs. The microbial processes that result in the conversion of DIN back to dinitrogen gas (N-loss) are the primary oceanic sinks for fixed nitrogen (Chang et al., 2010; Codispoti, 2007; Devol et al., 2006). These include water column and sedimentary denitrification $\left(\mathrm{NO}_{3}^{-} \rightarrow \mathrm{NO}_{2}^{-} \rightarrow \mathrm{N}_{2} \mathrm{O} \rightarrow \mathrm{N}_{2}\right.$ ), and anammox (anaerobic ammonium oxidation; $\mathrm{NO}_{2}^{-}+\mathrm{NH}_{4}^{+} \rightarrow \mathrm{N}_{2}$ ). Large-scale water column $\mathrm{N}$-loss in the global ocean occurs mainly in the three major oceanic oxygen minimum zones (eastern tropical North Pacific, eastern tropical South Pacific, and the Arabian Sea; Codispoti et al., 2001; Gruber and Sarmiento, 1997).

Several studies suggest that today's rate of ocean N-loss exceeds the rate of nitrogen fixation by over $200 \mathrm{Tg}$ per year (Brandes and Devol, 2002; Codispoti, 2007). This estimate is based in part on the accumulation of nitrate deficit (with respect to the Redfield N : P ratio [N*]; Gruber and Sarmiento, 1997) as a function of the residence time of oxygen-depleted 
water masses (Gruber, 2004; Gruber and Sarmiento, 1997, 2002). Whether this imbalance in the nitrogen inventory is due to an underestimation of nitrogen fixation or an overestimation of N-loss is a topic of current debate (Capone and Knapp, 2007; Codispoti, 2007; Deutsch et al., 2007; Dalsgaard et al., 2012; DeVries et al., 2012). More recently, the removal of fixed nitrogen has been estimated by measuring excess $\mathrm{N}_{2}\left(\mathrm{~N}_{2}^{\mathrm{xs}}\right.$, with respect atmospheric equilibrium), such as in the Arabian and Baltic Seas and the eastern tropical South Pacific (Chang et al., 2010; Devol et al., 2006; Löffler et al., 2011), in order to reduce uncertainties associated with regional variations in $\mathrm{N}: \mathrm{P}$ ratios and the complexities of DIN conversion pathways. DeVries et al. (2012) used $\mathrm{N}_{2}^{\mathrm{xS}}$ measurements coupled with a global circulation model to estimate oceanic water-column $\mathrm{N}$-loss rates. In anoxic waters of the Black Sea, interannual variations in $\mathrm{N}_{2}^{\mathrm{xS}}$ were attributed to changes in the downward flux of organic matter from phytoplankton blooms (Fuchsman et al., 2008). Despite these efforts many questions remain regarding the role of organic matter flux for fueling water column $\mathrm{N}$-loss (Brettar and Rheinheimer, 1992; Liu and Kaplan, 1984; Ward et al., 2008).

The Cariaco Basin offers an opportunity to examine the linkage between surface productivity and the loss of fixed nitrogen at depth. This basin exhibits water column $\mathrm{N}$-loss, high seasonal phytoplankton production $(\sim 700$ to $2300 \mathrm{mg} \mathrm{C} \mathrm{m}^{-2} \mathrm{~d}^{-1}$ ) and high vertical flux of particulate organic matter ( $\sim 40$ to $100 \mathrm{mg} \mathrm{C} \mathrm{m}^{-2} \mathrm{~d}^{-1}$; Muller-Karger et al., 2001; Scranton et al., 2006; Thunell et al., 2007; Zhang and Millero, 1993). One of the first measurements of marine $\mathrm{N}_{2}^{\mathrm{xS}}$ was conducted in the anoxic waters of the Cariaco Basin by Richards and Benson (1961) using $\mathrm{N}_{2}$ / Ar ratiometry. In this manuscript we build on Richards and Benson's work, and report new estimates of biogenic $\mathrm{N}_{2}$ gas production at several locations within the Cariaco Basin during upwelling and non-upwelling seasons. We tested the hypothesis that biogenic production of $\mathrm{N}_{2}$ varies both spatially and temporally within the anoxic waters of the basin in response to changes in the flux of organic matter. We also compared DIN deficits in the water column with $\mathrm{N}_{2}^{\mathrm{xs}}$ measurements to understand whether the removal of fixed nitrogen by denitrification was balanced by the biogenic production of $\mathrm{N}_{2}$. We assumed that heterotrophic (canonical water column denitrification) and chemoautotrophic (anammox) consumption of DIN were the only sources of biogenic $\mathrm{N}_{2}$ (Chang et al., 2010; Devol et al., 2006).

\section{Study area}

The Cariaco Basin is a $1400 \mathrm{~m}$ deep, tectonically derived depression on the continental shelf of Venezuela (Schubert, 1982; Fig. 1). Its sill $(\sim 100 \mathrm{~m})$ has two deeper channels, La Tortuga (135 m) and Centinela (145 m; Lidz et al., 1969; Richards, 1975). The exchange of water between the Cari- aco Basin and the Caribbean Sea/Atlantic Ocean is limited. Cariaco waters $>150 \mathrm{~m}$ deep are poorly ventilated; waters at the oxic-anoxic interface $(\sim 250 \mathrm{~m})$ have residence times of months to years, while bottom waters have residence times of years to decades (Holmén and Rooth, 1990; Zhang and Millero, 1993). The basin is subject to seasonal changes in the wind intensity along the coast related to the meridional migration of the Intertropical Convergence Zone, which drives alternating upwelling (January-May) and thermally stratified conditions (August-November) (Astor et al., 2003).

During upwelling, primary production (PP) and particulate organic matter (POM) vertical fluxes are high; the 14-yr PP and sediment trap particulate organic carbon (POC) flux $(225 \mathrm{~m})$ averages are $1871 \pm 394$ and $80 \pm 20 \mathrm{mg} \mathrm{C} \mathrm{m}^{-2} \mathrm{~d}^{-1}$, respectively (Muller-Karger et al., 2001, 2010). During the non-upwelling period, primary production and settling POC flux averages are significantly lower, $874 \pm 136 \mathrm{mg} \mathrm{C} \mathrm{m}^{-2} \mathrm{~d}^{-1}$ and $60 \pm 20 \mathrm{mg} \mathrm{C} \mathrm{m}^{-2} \mathrm{~d}^{-1}$, respectively.

The decomposition of the sinking POC contributes to present-day anoxic and sulfidic conditions below $\sim 250 \mathrm{~m}$ (Scranton et al., 2001; Zhang and Millero, 1993).

\section{Methods}

\subsection{Sample collection}

Samples were collected from the R/V Hermano Ginés during two cruises to Cariaco Basin (1-6 September 2008 and 9-13 March 2009). A total of 36 stations were occupied for general oceanographic observations during each cruise, while dissolved $\mathrm{N}_{2}$ samples were collected at six stations: three in the eastern sub-basin (stations 10, 11 and 13) and three in the western sub-basin (stations 21, 29 and 32) (Table 1, Fig. 1). These six stations all have water depths exceeding $300 \mathrm{~m}$ and included the oxic-anoxic interface. Hydrographic data were obtained using a Seabird ${ }^{\mathrm{TM}}$ SBE-25 conductivity-temperature-depth (CTD) device equipped with an Eco chlorophyll fluorometer (Wetlabs), an SBE43 dissolved oxygen sensor, and a rosette with 12 Teflon-coated $8 \mathrm{~L}$ Niskin bottles.

Stations 10 and 21 featured the deepest $(>1300 \mathrm{~m})$ profiles of anoxic waters. Station 10 is the location of the CARIACO Ocean Time Series Station $\left(10.5^{\circ} \mathrm{N}, 64.6^{\circ} \mathrm{W}\right)$, sampled monthly since November 1995 . Combined with stations 11 and 13, these three sites were chosen to help assess spatial changes in the eastern Cariaco Basin. Station 29 was sampled to investigate possible riverine influences on local hydrographic conditions, as it was closer to the mouth of the Tuy River, the largest river discharging into the Cariaco Basin. Finally, station 32 was selected to evaluate the effect of the influx of Caribbean waters through Centinela Channel (Fig. 1). 
Table 1. Location, profile depth, and chlorophyll $a$ concentration at the depth of chlorophyll maximum (DCM) at stations sampled for $\mathrm{N}_{2}^{\mathrm{xS}}$ during September 2008 and March 2009 in the Cariaco Basin.

\begin{tabular}{ccccccccc}
\hline & & & & \multicolumn{2}{c}{ September 2008 } & & \multicolumn{2}{c}{ March 2009 } \\
Station \# & $\begin{array}{c}\text { Latitude } \\
\left({ }^{\circ} \mathrm{N}\right)\end{array}$ & $\begin{array}{c}\text { Longitude } \\
\left({ }^{\circ} \mathrm{W}\right)\end{array}$ & $\begin{array}{c}\text { Profile } \\
\text { depth }(\mathrm{m})\end{array}$ & $\begin{array}{c}{[\mathrm{Chl} a]} \\
\left(\mu \mathrm{L} \mathrm{L}^{-1}\right)\end{array}$ & $\begin{array}{c}\text { DCM } \\
(\mathrm{m})\end{array}$ & & $\begin{array}{c}{[\mathrm{Chl} a]} \\
\left(\mu \mathrm{g} \mathrm{L}^{-1}\right)\end{array}$ & $\begin{array}{c}\text { DCM } \\
(\mathrm{m})\end{array}$ \\
\hline 10 & 10.5 & 64.7 & 1300 & 0.31 & 50 & & 0.60 & 20 \\
11 & 10.7 & 64.7 & 400 & 0.61 & 57 & & 0.60 & 33 \\
13 & 10.5 & 65.0 & 400 & 0.63 & 61 & & 0.54 & 42 \\
21 & 10.7 & 65.7 & 1300 & 0.42 & 50 & & 1.25 & 43 \\
29 & 10.7 & 65.9 & 400 & 0.42 & 65 & & 1.15 & 38 \\
32 & 10.8 & 65.7 & 400 & 0.52 & 50 & & 2.10 & 50 \\
\hline
\end{tabular}

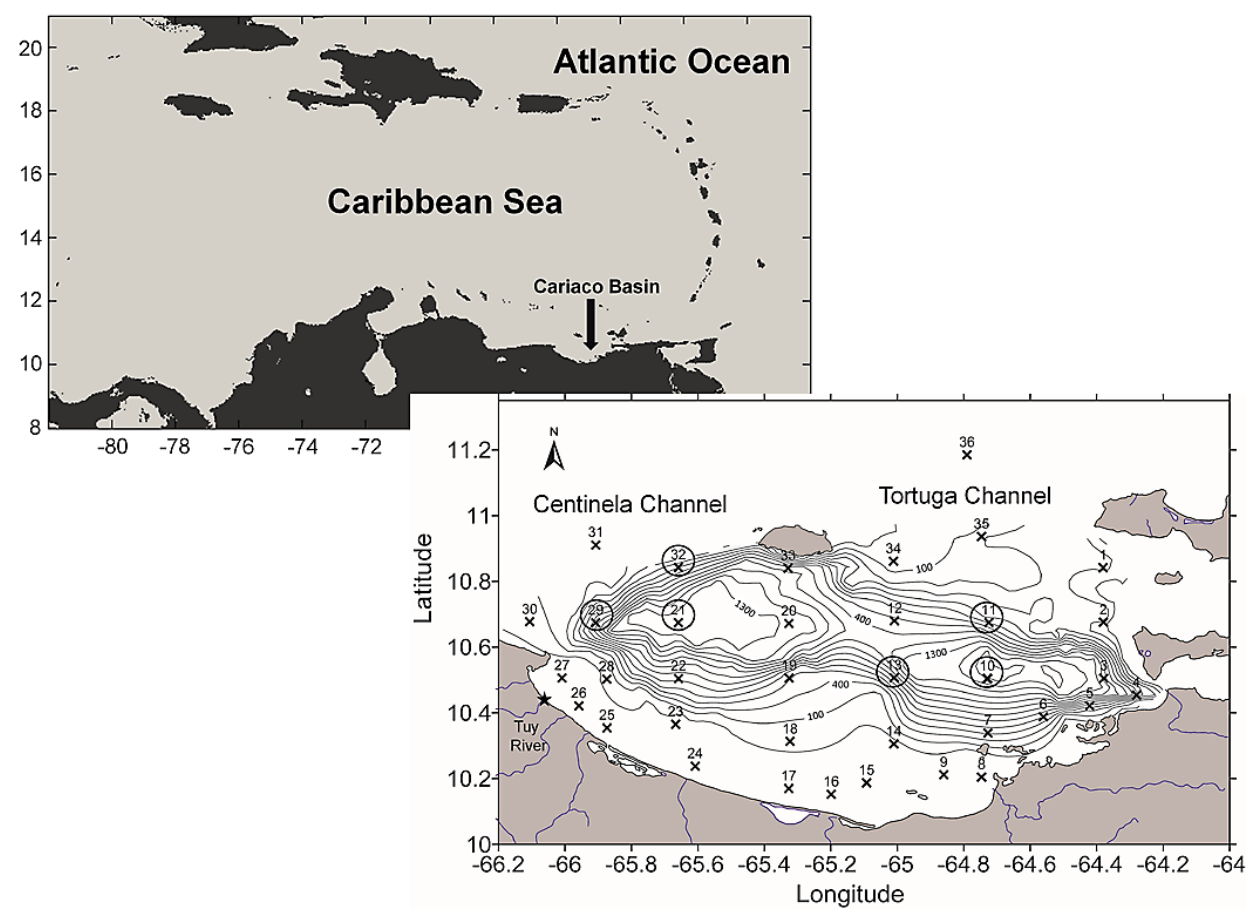

Fig. 1. Location of the Cariaco Basin and stations sampled for $\mathrm{N}_{2}^{\mathrm{xs}}$ (circles) in September 2008 and March 2009. Station 10 corresponds to the CARIACO Ocean Time Series Station $\left(10.5^{\circ} \mathrm{N}, 64.7^{\circ} \mathrm{W}\right)$. Broken lines trace the bathymetry of the basin. The black star shows the location of the Tuy River mouth.

Chlorophyll $a$ and nutrient samples were collected at the 36 stations during each cruise, from the surface to 100 $\mathrm{m}(1,20,30,50,100 \mathrm{~m})$; below this depth chlorophyll concentrations are typically below the detection limit of $0.01 \mu \mathrm{g} \mathrm{L}^{-1}$. Chlorophyll $a$ determinations were carried out using methanol extractions (see Muller-Karger et al., 2001) and a Turner Designs model 10 fluorometer as described by Falkowski and Kiefer (1985) and Holm-Hansen et al. (1965).

DIN and soluble reactive phosphorus (SRP) samples were collected at 1,20,50 and $100 \mathrm{~m}$ at stations $10,11,13$ and 29 , and at the surface at stations 21 and 32 . Additional nitrate and ammonium samples were collected at 200, 250, 300 and $400 \mathrm{~m}$. Nutrient data from the CARIACO Ocean
Time Series Station (station 10 in Fig. 1) collected during September 2008 and March 2009 were used in this study as well (data available at the CARIACO Ocean Time Series website: http://www.imars.usf.edu/CAR/). Nutrient determinations were conducted at the University of South Florida following the protocols of Gordon et al. (2000) and Strickland and Parsons (1972). We used $\mathrm{H}_{2} \mathrm{~S}$ measurements from samples collected on separate cruises at the CARIACO Station between 2007 and 2009 (April and November 2007, May 2008, and January and May 2009) since sulfide determinations were not conducted during our cruises. These sulfide data are presented in Li et al. $(2008,2010)$. 
Water for the dissolved $\mathrm{N}_{2}$ analyses was collected using Niskin bottles at 1, 50,100,200, 275, 300, and $400 \mathrm{~m}$ at the six stations selected for this study. At stations 10 and 21, additional samples were collected at 500, 750, and $1300 \mathrm{~m}$. Samples were collected using $60 \mathrm{~mL}$ biological oxygen demand (BOD) bottles using the filling procedure for Winkler $\mathrm{O}_{2}$ determinations. A $100 \mu \mathrm{L}$ aliquot of saturated $\mathrm{HgCl}_{2}$ was added to each sample for preservation. Bottles were sealed with glass stoppers, and standing seawater was left around the exterior of the glass stopper at the mouth of the bottle to inhibit gas exchange with the atmosphere. The mouth of the BOD bottles, including the stopper and standing water, were sealed with a plastic cap to avoid spilling of the standing seawater, and samples were kept in a cooler or refrigerator at $\sim 4^{\circ} \mathrm{C}$ until analyzed.

\subsection{Gas analyses}

High-precision estimates of nitrogen gas were conducted at the School of Marine Science and Technology, University of Massachusetts Dartmouth, using isotope ratio mass spectrometry (IRMS). Dissolved gases were extracted from each sample by pumping an aliquot at $10 \mathrm{~mL} \mathrm{~min}^{-1}$ through a chambered microfiber-microporous gas extractor coupled to a continuous flow of $\mathrm{He}$ carrier gas. The extracted gas was then passed through water, $\mathrm{CO}_{2}$ and $\mathrm{O}_{2}$ traps before transferring to a GV IsoPrime IRMS for simultaneous measurements of $\mathrm{N}_{2}$ (mass 28) and $\mathrm{Ar}$ (mass 40). A liquid nitrogen cold trap was also used to remove $\mathrm{H}_{2} \mathrm{~S}$ from samples collected within the sulfidic portion of the water column. Gas ratios from samples were compared against calibrated references of artificial compressed gas mixtures of $\mathrm{N}_{2}$ and $\mathrm{Ar}$ covering the expected dissolved gas ratios. Further calibration also included comparing gas measurements in distilled water equilibrated with air at controlled temperatures of 10 and $20^{\circ} \mathrm{C}\left( \pm 0.01^{\circ} \mathrm{C}\right)$ to theoretical determinations based on the solubility of these gases. The analytical precision of $\mathrm{N}_{2} / \mathrm{Ar}$ measurements was better than $0.3 \%$, and thus the limit of detection of $\mathrm{N}_{2}$ was $\sim 0.3 \mu \mathrm{mol} \mathrm{kg}^{-1}$.

$\mathrm{N}_{2}^{\mathrm{xS}}$ was calculated from deviations of the sample $\mathrm{N}_{2} / \mathrm{Ar}$ ratio from equilibrium values expected from in situ measurements of potential temperature and salinity (Hamme and Emerson, 2004). This largely eliminates artifacts related to changes in gas concentration caused by physical effects on the dissolution of $\mathrm{N}_{2}$ due to variations in temperature and salinity. $\mathrm{N}_{2}$ / Ar ratios were, in turn, normalized to ratios at atmospheric equilibrium $\left(\mathrm{N}_{2}: \mathrm{Ar}_{\text {sample }} / \mathrm{N}_{2}: \mathrm{Ar}_{\text {atm. equilibrium }}\right)$ to detect departures of $\mathrm{N}_{2}$ concentrations from expected equilibrium values due to biogenic $\mathrm{N}_{2}$ production. $\mathrm{N}_{2}^{\mathrm{xs}}$ can also arise from physical processes in the near-surface region influencing air-sea gas exchange. Positive $\mathrm{N}_{2}^{\mathrm{xs}}$ is produced by air injection due to bubble collapse that can occur in remote water mass formation regions (Hamme and Emerson, 2002; Hamme and Severinghaus, 2007), whereas negative anomalies can arise locally by in situ heating when there is diminished exchange with the atmosphere.

Background (or abiotic) $\mathrm{N}_{2}$ / Ar ratios in the Cariaco Basin were estimated based on data collected at the Bermuda Atlantic Time Series Station (BATS) (Nicholson et al., 2010; M. Altabet, unpublished data, 2012). Normalized $\mathrm{N}_{2}$ / Ar ratios at BATS are near atmospheric equilibrium in surface waters $\left(\sim 27^{\circ} \mathrm{C}\right)$ and $\sim 1.5 \%$ supersaturated at $1000 \mathrm{~m}\left(\sim 6^{\circ} \mathrm{C}\right.$ waters). Background $\mathrm{N}_{2}$ / Ar ratios in the Cariaco Basin were then derived from the linear regression equation for the correlation between salinity-normalized temperature and measured $\mathrm{N}_{2} /$ Ar ratios at BATS $\left(y=-0.0232 x+1.0176 ; R^{2}=\right.$ 0.88). Our background $\mathrm{N}_{2} / \mathrm{Ar}$ ratio estimates in Cariaco are based upon the assumption that Subtropical Underwater (SUW), the major source water to the basin, has a similar vertical distribution of $\mathrm{N}_{2}$ / Ar supersaturation to that observed at BATS since SUW is formed in the eastern subtropical North Atlantic.

\section{Results}

\subsection{Hydrographic data}

Profiles of dissolved oxygen $\left(\mathrm{O}_{2}\right)$ concentration and density $\left(\sigma_{\theta}\right)$ were measured at the six stations sampled for gas analyses during September 2008 and March 2009 (Fig. 2). For both seasons, oxygen concentrations decreased from $\sim 185 \pm 12 \mu \mathrm{mol} \mathrm{kg}^{-1}$ at the surface to below detection at $300 \mathrm{~m}$. There was higher $\left[\mathrm{O}_{2}\right]$ at the $\sim 25-26$ isopycnal surface $(\sim 0-120 \mathrm{~m})$ in March 2009 likely as a result of increased vertical mixing and ventilation; the $\left[\mathrm{O}_{2}\right]$ at 25 isopycnal was $\sim 35 \mu \mathrm{mol} \mathrm{kg}^{-1}$ higher in March 2009 than in September 2008. Sulfide was detected immediately below the depth at which oxygen was below detection $\left(\left[\mathrm{H}_{2} \mathrm{~S}\right]>1 \mu \mathrm{mol} \mathrm{kg}{ }^{-1}\right.$ at $\left.270 \mathrm{~m}\right)$ between 2007 and 2009 and increased with depth to a mean maximum value of $65 \pm 3 \mu \mathrm{mol} \mathrm{kg}^{-1}$ at $1300 \mathrm{~m}$.

A plot of salinity $(S)$ versus potential temperature $(\theta)$ for the six stations selected for excess $\mathrm{N}_{2}$ measurements during the two cruises indicates that water masses below $\sim 150 \mathrm{~m}$ in the Cariaco Basin during the two sampling periods were similar (Fig. 3). During September 2008, stations in the western sub-basin (stations 21, 29 and 32) showed lower salinities near the surface than those in the eastern sub-basin (stations 10,11 and 13). This surface water is derived from the western tropical North Atlantic and the Caribbean Sea. The salinity maximum, which is associated with SUW, shows a slight warming during the upwelling season when this water mass is closer to the surface and therefore exposed to sunlight.

\subsection{Nutrients and chlorophyll $a$}

Nutrient concentrations at the surface were nearly undetectable during both seasons due to biological uptake. They were slightly higher in the upper $50 \mathrm{~m}$ at the six stations 


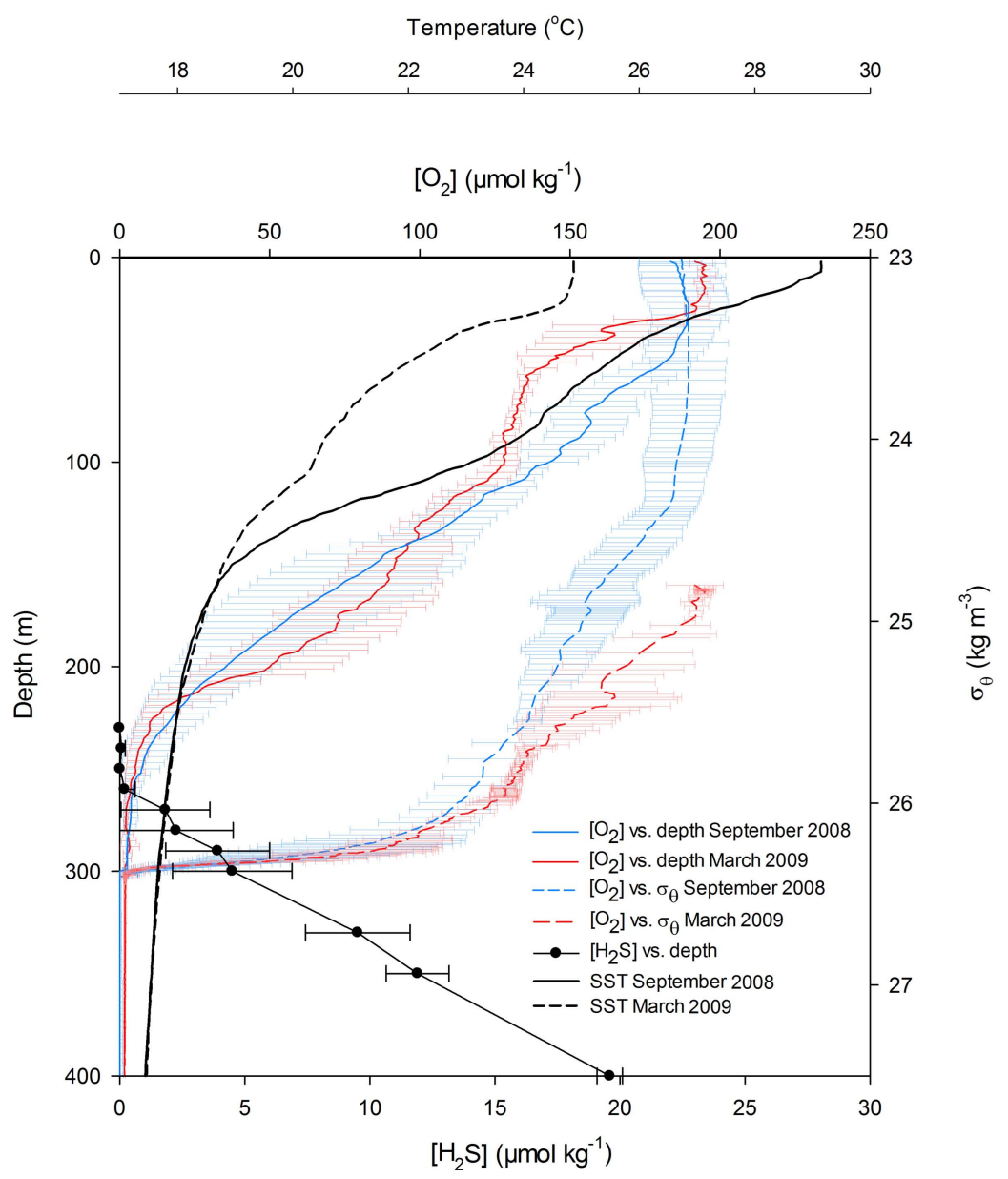

Fig. 2. Profiles of mean $\left[\mathrm{O}_{2}\right],\left[\mathrm{H}_{2} \mathrm{~S}\right]$ and water column temperature versus depth in the upper $400 \mathrm{~m}$ of the Cariaco Basin. Oxygen and temperature profiles are constructed from data collected at all six stations sampled during September 2008 and March 2009 for $\mathrm{N}_{2}^{\mathrm{XS}}$ determinations. Average $\left[\mathrm{H}_{2} \mathrm{~S}\right]$ was calculated from data collected on separate cruises at the CARIACO Station between 2007 and 2009 (see Sect. 3.1). Mean oxygen concentrations are also plotted against density $\left(\sigma_{\theta}\right)$.

sampled for gas determinations (Table 2) in March 2009 as a result of upwelling, compared to September 2008. Nitrite and SRP concentrations in the top $100 \mathrm{~m}$ were below $1 \mu \mathrm{mol} \mathrm{kg}^{-1}$ in both seasons. A peak in $\left[\mathrm{NO}_{3}^{-}\right]$of $10-12 \mu \mathrm{mol} \mathrm{kg}^{-1}$ was observed around $200 \mathrm{~m}$, and $\left[\mathrm{NO}_{3}^{-}\right]$was below detection at $300 \mathrm{~m}$. Ammonium concentrations were low but variable near the surface $\left(<0.5 \mu \mathrm{mol} \mathrm{kg}{ }^{-1}\right)$, with slightly higher values in the upper $50 \mathrm{~m}$ during March 2009 compared to September 2008. Ammonium concentrations showed a minimum at $200 \mathrm{~m}$ in both seasons. From $250 \mathrm{~m}$ to the bottom, $\left[\mathrm{NH}_{4}^{+}\right]$increased at a rate of $\sim 0.04 \mu \mathrm{mol} \mathrm{kg}{ }^{-1} \mathrm{~m}^{-1}$ reaching values as high as $\sim 23 \mu \mathrm{mol} \mathrm{kg}^{-1}$ at $1300 \mathrm{~m}$ (stations 10 and 21; data not shown).

Samples collected at selected stations for $\mathrm{N}_{2}^{\mathrm{xs}}$ measurements showed nutrient concentrations similar to those from the CARIACO Ocean Time Series during corresponding months (September 2008 and March 2009; Fig. 4). As expected, all nutrient measurements in the upper $100 \mathrm{~m}$ from the CARIACO Ocean Time Series showed higher concentrations in March 2009 (upwelling conditions) than in September 2008 (non-upwelling conditions). Nitrite showed a large peak at $100 \mathrm{~m}$ in September 2008, but a secondary peak near the oxic-anoxic interface was not detected during this time, possibly due to wide sample spacing. In March 2009, however, a sharp secondary nitrite maximum $\left(0.86 \mu \mathrm{mol} \mathrm{kg}{ }^{-1}\right)$ was measured at $\sim 270 \mathrm{~m}$. Nitrate, SRP and ammonium concentrations below $100 \mathrm{~m}$ showed similar vertical profiles during both periods.

A deep chlorophyll maximum (DCM) was observed at 50$65 \mathrm{~m}$ in September $2008\left(0.48 \pm 0.12 \mu \mathrm{g} \mathrm{L}^{-1}\right.$; Table 1$)$, and at $20-50 \mathrm{~m}$ in March $2009\left(1.04 \pm 0.60 \mu \mathrm{g} \mathrm{L}^{-1}\right)$. This shoaling of the DCM is characteristic of the upwelling season (Astor et al., 2003). Chlorophyll $a$ concentrations at the DCM in the eastern sub-basin were on the order of $0.60 \mu \mathrm{g} \mathrm{L}^{-1}$, while in the western sub-basin concentrations ranged 1.15$2.10 \mu \mathrm{g} \mathrm{L}^{-1}$. 
Table 2. Average nutrient concentrations from stations sampled for $\mathrm{N}_{2}^{\mathrm{xs}}$ determinations during September 2008 and March 2009 in the Cariaco Basin. Values near the oxic-anoxic interface are shown in bold captions.

\begin{tabular}{|c|c|c|c|c|c|c|c|c|c|c|c|c|c|c|c|c|}
\hline \multirow[b]{2}{*}{$\begin{array}{r}\text { Depth } \\
\text { (m) }\end{array}$} & \multicolumn{8}{|c|}{ 1-6 September 2008} & \multicolumn{8}{|c|}{ 9-13 March 2009} \\
\hline & $\begin{array}{c}{\left[\mathrm{NO}_{3}^{-}\right]} \\
(\mu \mathrm{mol} \\
\left.\mathrm{kg}^{-1}\right)\end{array}$ & SD & $\begin{array}{r}{\left[\mathrm{NO}_{2}^{-}\right]} \\
(\mu \mathrm{mol} \\
\left.\mathrm{kg}^{-1}\right)\end{array}$ & SD & $\begin{array}{c}{\left[\mathrm{NH}_{4}^{+}\right]} \\
(\mu \mathrm{mol} \\
\left.\mathrm{kg}^{-1}\right)\end{array}$ & SD & $\begin{array}{r}{\left[\mathrm{PO}_{4}^{3-}\right]} \\
(\mu \mathrm{mol} \\
\left.\mathrm{kg}^{-1}\right)\end{array}$ & SD & $\begin{array}{r}{\left[\mathrm{NO}_{3}^{-}\right]} \\
(\mu \mathrm{mol} \\
\left.\mathrm{kg}^{-1}\right)\end{array}$ & SD & $\begin{array}{r}{\left[\mathrm{NO}_{2}^{-}\right]} \\
(\mu \mathrm{mol} \\
\left.\mathrm{kg}^{-1}\right)\end{array}$ & SD & $\begin{array}{r}{\left[\mathrm{NH}_{4}^{+}\right]} \\
(\mu \mathrm{mol} \\
\left.\mathrm{kg}^{-1}\right)\end{array}$ & SD & $\begin{array}{r}{\left[\mathrm{PO}_{4}^{3-}\right]} \\
(\mu \mathrm{mol} \\
\left.\mathrm{kg}^{-1}\right)\end{array}$ & SD \\
\hline 1 & 0.16 & 0.17 & 0.03 & 0.02 & 0.25 & 0.11 & 0.01 & 0.01 & 0.31 & 0.46 & 0.05 & 0.03 & 0.38 & 0.37 & 0.01 & 0.01 \\
\hline 20 & 0.21 & 0.20 & 0.01 & 0.01 & 0.20 & 0.07 & 0.01 & 0.01 & 1.78 & 1.40 & 0.10 & 0.11 & 0.79 & 0.46 & 0.04 & 0.01 \\
\hline 50 & 0.35 & 0.25 & 0.02 & 0.02 & 0.34 & 0.17 & 0.02 & 0.00 & 4.59 & 2.02 & 0.32 & 0.06 & 0.64 & 0.64 & 0.47 & 0.35 \\
\hline 100 & 4.66 & 0.69 & 0.15 & 0.07 & 0.17 & 0.06 & 0.25 & 0.04 & 8.09 & 0.72 & 0.13 & 0.05 & 0.30 & 0.33 & 0.43 & 0.03 \\
\hline 200 & 10.37 & 2.10 & & & 0.03 & 0.04 & & & 10.38 & 0.90 & & & 0.13 & & & \\
\hline 250 & 4.28 & 3.98 & & & 1.08 & 0.51 & & & 3.71 & 2.02 & & & 1.32 & 0.44 & & \\
\hline 300 & 0.39 & 0.16 & & & 3.66 & 1.28 & & & 0.39 & 0.23 & & & 2.91 & 1.51 & & \\
\hline 400 & 0.00 & 0.00 & & & 8.10 & 1.05 & & & 0.00 & 0.00 & & & 7.81 & 2.48 & & \\
\hline
\end{tabular}

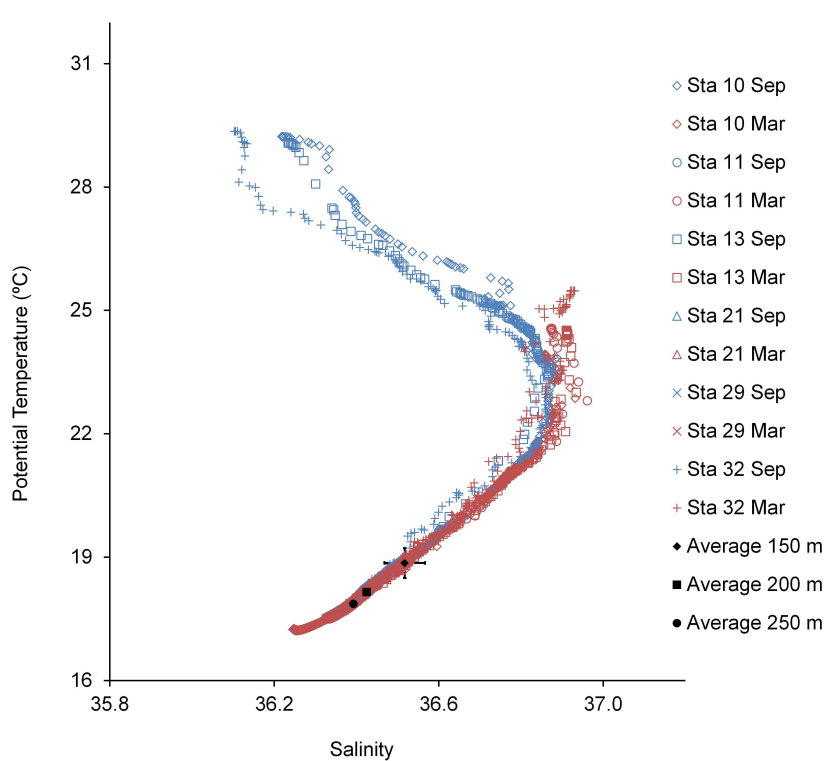

Fig. 3. Salinity versus potential temperature $(\theta)$ in the Cariaco Basin at stations sampled for $\mathrm{N}_{2}^{\mathrm{Xs}}$ measurements during September 2008 and March 2009. Black symbols represent the average potential temperature and salinity from all six stations and sampling periods at 150 (diamond), 200 (square) and 250 (circle) meters.

\section{3 $\quad \mathrm{N}_{2}$ / Ar ratios and $\mathrm{N}_{2}^{\mathrm{xs}}$}

Average vertical distributions of normalized $\mathrm{N}_{2} / \mathrm{Ar}$ ratios during both cruises are shown in Fig. 5a. Average normalized $\mathrm{N}_{2} / \mathrm{Ar}$ ratios measured in the upper $100 \mathrm{~m}$ were undersaturated by $\sim 0.5 \%$ in September 2008 and $\sim 0.2 \%$ in March 2009. The mean $\mathrm{N}_{2}$ / Ar ratio near the oxic-anoxic interface $(250-300 \mathrm{~m})$ was $1.026(\sim 2.6 \%$ supersaturated $)$ during both periods. Below this depth, $\mathrm{N}_{2} / \mathrm{Ar}$ ratios remained fairly constant. Estimates of background $\mathrm{N}_{2}$ / Ar ratios (calculated based on regressions of the ratio versus temperature reported at BATS) in surface waters were close to atmospheric equilibrium in September 2008 and $\sim 0.3 \%$ supersaturated in
March 2009. Corresponding background $\left[\mathrm{N}_{2}^{\mathrm{xs}}\right]$ in the upper $100 \mathrm{~m}$ showed negative values in September 2008 and positive values in March $2009\left(\sim 2 \mu \mathrm{mol} \mathrm{N} \mathrm{kg}{ }^{-1}\right.$; Fig. 5b). Estimated background $\mathrm{N}_{2}$ / Ar ratios peaked at $200 \mathrm{~m}(\sim 0.6 \%$ supersaturation) with background $\left[\mathrm{N}_{2}^{\mathrm{xs}}\right]$ at $\sim 6 \mu \mathrm{mol} \mathrm{N} \mathrm{kg}{ }^{-1}$ during both periods and remaining constant below this depth (Fig. 5a, b).

In March 2009, observed $\mathrm{N}_{2}^{\mathrm{xs}}$ in surface waters was closer to equilibrium with the atmosphere. In September 2008, waters in the upper $100 \mathrm{~m}$ had observed $\mathrm{N}_{2}^{\mathrm{xs}}$ negative anomalies as high as $\sim 8 \mu \mathrm{mol} \mathrm{Ng}^{-1}$, presumably in response to stratification and warming by $4{ }^{\circ} \mathrm{C}$ as compared to March 2009. Waters $\geq 200 \mathrm{~m}$ were supersaturated with dissolved $\mathrm{N}_{2}$ at all stations during both cruises. Below the upper $150 \mathrm{~m}$, observed $\left[\mathrm{N}_{2}^{\mathrm{xs}}\right]$ rapidly increased to peak concentrations near the oxic-anoxic interface (250-300 m). In March 2009 , [ $\left.\mathrm{N}_{2}^{\mathrm{xs}}\right]$ decreased by $\sim 3 \mu \mathrm{mol} \mathrm{N} \mathrm{kg}^{-1}$ from these maximal values at depths below $400 \mathrm{~m}$. In addition, samples collected between $300-400 \mathrm{~m}$ at four stations during the upwelling period (March 2009) had significantly higher $\left[\mathrm{N}_{2}^{\mathrm{xS}}\right]$ $\left(2.7-6.1 \mu \mathrm{mol} \mathrm{N} \mathrm{kg}{ }^{-1}, p<0.001\right)$ than those at the same stations during the relaxation period (September 2008) (Fig. 6). This was not observed at stations 10 (in the center of the eastern basin) and 29 (in the western basin near the Tuy River). However, we did not detect a clear spatial pattern along sampled stations which would have suggested an influence from riverine discharge or Caribbean waters entering into the basin through the Centinela and Tortuga channels (Fig. 1) on $\mathrm{N}_{2}^{\mathrm{xs}}$ distributions.

\section{Discussion}

\section{$5.1 \quad \mathrm{~N}_{2} /$ Ar ratios and $\mathrm{N}_{2}^{\mathrm{xs}}$}

Surface waters of the Cariaco Basin showed negative $\mathrm{N}_{2}^{\mathrm{xs}}$ anomalies during both periods (Fig. $5 \mathrm{a}$ and $5 \mathrm{~b}$ ). The magnitude of $\mathrm{N}_{2}^{\mathrm{xs}}$ negative anomalies was lower in March 2009 than in September 2008, when sea surface temperatures 

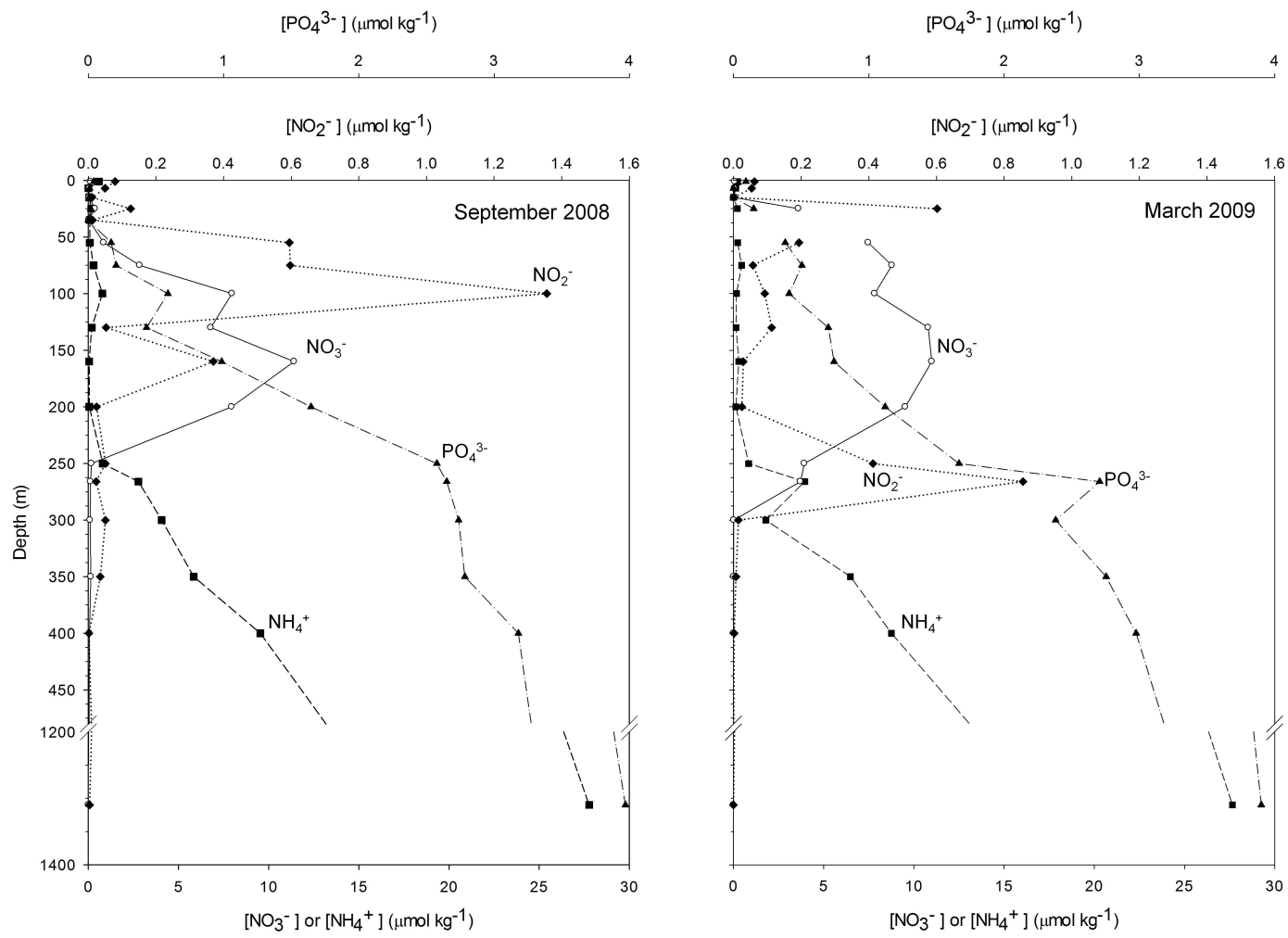

Fig. 4. Nutrient profiles from the CARIACO Time Series Station during September 2008 and March 2009.

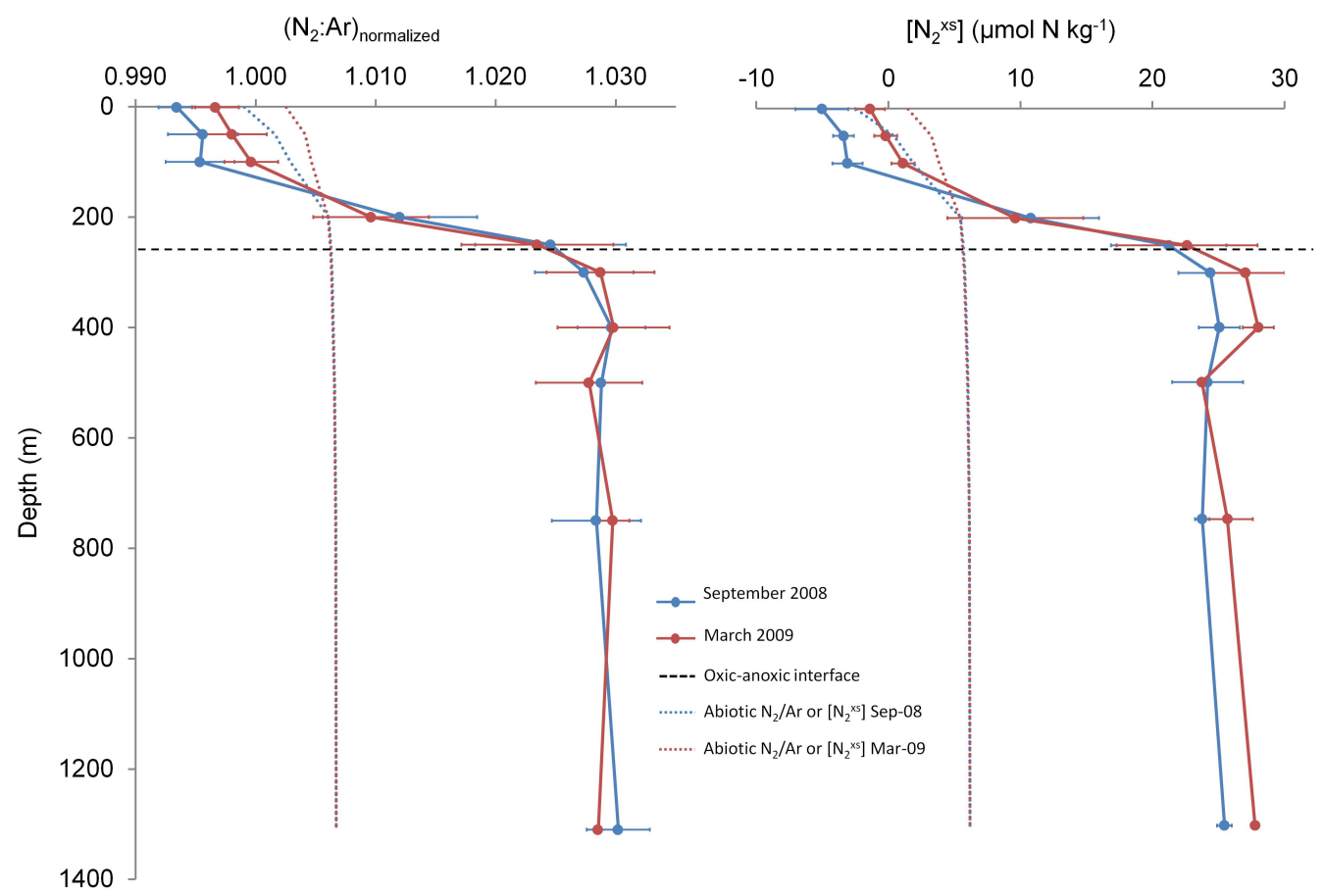

Fig. 5. Profiles of normalized $\mathrm{N}_{2} /$ Ar ratios and $\left[\mathrm{N}_{2}^{\mathrm{xs}}\right]$ in the Cariaco Basin during September 2008 and March 2009. Background (abiotic) $\mathrm{N}_{2}$ / Ar ratios and [ $\left.\mathrm{N}_{2}^{\mathrm{XS}}\right]$ were estimated using data collected at BATS (see Sect. 3.2). 


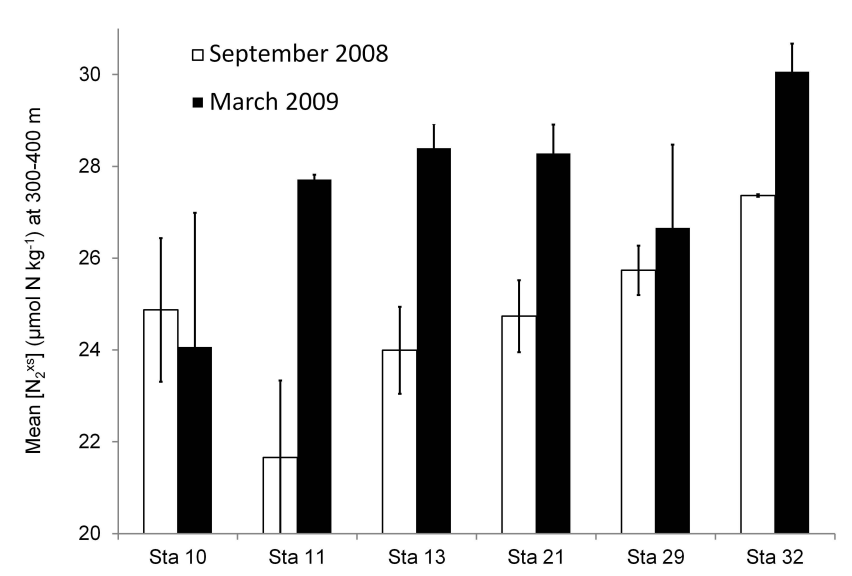

Fig. 6. Mean $\left[\mathrm{N}_{2}^{\mathrm{Xs}}\right]$ between 300 and $400 \mathrm{~m}$ in the Cariaco Basin from all six stations sampled during September 2008 and March 2009.

(SST) were significantly higher $\left(>29^{\circ} \mathrm{C}\right)$. Hence, in situ near-surface water heating without gas re-equilibration is the most likely cause for the negative values of $\mathrm{N}_{2}^{\mathrm{xS}}$. Increasing SST reduces the equilibrium concentration of $\mathrm{N}_{2}$ to a lesser degree than $\mathrm{Ar}$, thereby increasing equilibrium $\mathrm{N}_{2} / \mathrm{Ar}$. If actual $\mathrm{N}_{2}$ and $\mathrm{Ar}$ concentrations have little to no change due to low air-sea gas exchange, then the observed $\mathrm{N}_{2}$ / Ar is less than the equilibrium value and a negative $\left[\mathrm{N}_{2}^{\mathrm{xS}}\right]$ results. Calculations (not shown) show that the magnitude of observed negative $\left[\mathrm{N}_{2}^{\mathrm{xs}}\right]$ is consistent with the seasonal temperature increase assuming in situ heating with minimal gas exchange.

$\left[\mathrm{N}_{2}^{\mathrm{xS}}\right]$ values were relatively constant with depth in the upper $100 \mathrm{~m}$ during both sampling periods but increased below $200 \mathrm{~m}$, as dissolved oxygen decreased and N-loss began. The $\left[\mathrm{NO}_{3}^{-}\right]$profile shows the consumption of nitrate by denitrification between $\sim 200$ and $300 \mathrm{~m}$ (Fig. 4). In most stations, the highest $\left[\mathrm{N}_{2}^{\mathrm{xs}}\right]\left(\sim 12-30 \mu \mathrm{mol} \mathrm{N} \mathrm{kg}^{-1}\right.$; average $=23.8 \pm 4.3 \mu \mathrm{mol} \mathrm{N} \mathrm{kg}{ }^{-1}$ ) was measured at $250-300 \mathrm{~m}$ (Fig. 5). The mean $\left[\mathrm{N}_{2}^{\mathrm{xs}}\right]$ between the oxic-anoxic interface $(250 \mathrm{~m})$ and $1300 \mathrm{~m}$ depth was $25 \pm 2 \mu \mathrm{mol} \mathrm{Ng}^{-1}$, which is equivalent within uncertainty to the increase in $\mathrm{N}_{2}^{\mathrm{xs}}$ expected from the $\mathrm{N}$ deficit $\left(\sim 23 \mu \mathrm{mol} \mathrm{Nkg}^{-1}\right)$. Our primary assumption is that the basin is filled with sill-depth $(\sim 150 \mathrm{~m})$ Caribbean Sea intermediate waters that were once fully oxygenated, as previously proposed by Richard and Benson (1961). In the Cariaco Basin nitrogen derives from two sources: incoming nitrate and $\mathrm{N}$ from remineralized organic matter. Unpublished data show that nitrate and oxygen concentrations in Caribbean intermediate waters entering the basin are 6-8 and $\sim 140 \mu \mathrm{mol} \mathrm{kg}{ }^{-1}$, respectively (L. Lorenzoni unpublished data, 2004). Subsequent lack of ventilation induces today's anoxic conditions and thus denitrification leading to an $\mathrm{N}$ deficit and buildup of $\mathrm{N}_{2}^{\mathrm{xs}}$ above preexisting background levels. The consumption of nitrate by denitrification would thus have generated $\sim 7 \mu \mathrm{mol} \mathrm{N} \mathrm{kg}{ }^{-1}$ of $\mathrm{N}_{2}^{\mathrm{xs}}$, while the consumption of oxygen by organic mat- ter remineralization would have produced $\sim 16 \mu \mathrm{mol} \mathrm{kg}-1$ of DIN available for N-loss (AOU : $N=\sim 270: 16$ ) for an expected total of $\sim 23 \mu \mathrm{mol} \mathrm{Ng}^{-1}$ of $\mathrm{N}_{2}^{\mathrm{xs}}$ produced. Oxygen consumption by organic matter remineralization would have released ammonium $\left(\sim 16 \mu \mathrm{mol} \mathrm{kg}^{-1}\right)$ that would have subsequently been either directly consumed by anammox or transformed into $\mathrm{NO}_{x}$ available for denitrification. The entire process is likely very dynamic and the observed $\mathrm{N}_{2}^{\mathrm{xs}}$ in the Cariaco Basin is the result of multiple pulses of Caribbean Sea intermediate waters flowing over the sill into the suboxic and anoxic portions of the basin. Evidence of such intrusion events have been reported by Astor et al. (2003) and Scranton et al. (2006). Nitrate from intrusions into the oxicanoxic interface would be consumed by denitrification while that injected into the sulfidic portion of the water column would be consumed by autotrophic denitrification, a biological process that uses sulfur species as reductant to convert nitrate into $\mathrm{N}_{2}$ (Fuchsman et al., 2012; Jensen et al., 2009). Though an overlap between sulfide and nitrate has not been detected in the basin (M. Scranton, personal communication, 2012) and incubations have not shown any stimulation of dark carbon fixation by nitrate, previous work has reported high rates of dark dissolved inorganic carbon (DIC) fixation (chemoautotrophy) occurring at the oxic-anoxic interface in the Cariaco Basin (Taylor et al., 2001, 2006; Wakeham et al., 2012).

Our profiles of $\mathrm{N}_{2} /$ Ar ratios and $\left[\mathrm{N}_{2}^{\mathrm{xs}}\right]$ are similar in shape to the earlier profiles measured by Richards and Benson (1961) in the Cariaco Basin. They found an average $\left[\mathrm{N}_{2}^{\mathrm{xs}}\right]$ of $20.7 \pm 2.1 \mu \mathrm{mol} \mathrm{kg}^{-1}$ at $\sim 400-1200 \mathrm{~m}$, or $\sim 25 \%$ lower than our average $\left[\mathrm{N}_{2}^{\mathrm{xs}}\right]$ of $25.0 \pm 1.8 \mu \mathrm{mol} \mathrm{N} \mathrm{kg}^{-1}$ in the same depth range in the eastern sub-basin (stations 10, 11 and 13). It is unlikely that such difference in $\left[\mathrm{N}_{2}^{\mathrm{xs}}\right]$ results from methodological discrepancies. Richards and Benson's $\mathrm{N}_{2}^{\mathrm{xs}}$ measurements were carried out following the methods described in Benson and Parker (1961). Differences between their methodology and ours included sample storage in specially made piston sealed bottles and dissolved gas extraction on a vacuum line prior to transfer to a mass spectrometer using a Toepler pump. They also removed $\mathrm{O}_{2}$ using hot copper prior to $\mathrm{N}_{2}$ / Ar analysis. While the method used by Richards and Benson (1961) is more time-consuming than ours, there is no reason to suspect a systematic bias between our approaches as they also determined that they achieved quantitative gas extraction. In fact, Richards and Benson (1961) also observed slight negative $\left[\mathrm{N}_{2}^{\mathrm{xS}}\right]$ of 1 to $3 \mu \mathrm{mol} \mathrm{N} \mathrm{kg}{ }^{-1}$ as we do. Such agreement would be unlikely if either of our methods has significant bias. To our knowledge, these are the only two studies of $\mathrm{N}_{2}^{\mathrm{xs}}$ that have been conducted in the Cariaco Basin. The difference suggests that $\mathrm{N}_{2}^{\mathrm{xs}}$ has been accumulating in the basin at a rate of $\sim 0.08 \mu \mathrm{mol} \mathrm{N} \mathrm{kg} \mathrm{yr}^{-1}$ (from 1957 to 2009) within this depth interval $(\sim 400$ $1200 \mathrm{~m})$. We see a concurrent increase in SRP, ammonium and silicate concentrations $(0.035-0.037,0.28-0.62$ 
and $0.85-1.3 \mu \mathrm{mol} \mathrm{kg}{ }^{-1} \mathrm{yr}^{-1}$, respectively; Scranton et al., 2006; Zhang and Millero, 1993) The increase in SRP better matches Redfield stoichiometry $(15-16: 1 \mathrm{~N}: \mathrm{P})$ when both the accumulation rate of $\mathrm{N}_{2}^{\mathrm{xs}}\left(0.08 \mu \mathrm{mol} \mathrm{N} \mathrm{kg}^{-1} \mathrm{yr}^{-1}\right)$ and ammonium $\left(0.45 \mu \mathrm{mol} \mathrm{N} \mathrm{kg}^{-1} \mathrm{yr}^{-1}\right.$; average based on values reported above) are accounted for. The DIN / SRP ratio of the accumulation is $14.7([0.08+0.45]: 0.036)$ if $\mathrm{N}_{2}^{\mathrm{xS}}$ is included and 12.5 when it is not.

\subsection{Biogenic $\mathrm{N}_{2}$ production and upwelling}

The $\left[\mathrm{N}_{2}^{\mathrm{xs}}\right]$ measured immediately below the oxic-anoxic interface at 300-400 $\mathrm{m}$ in March 2009 (upwelling) is higher than that measured in September $2008(p<0.001)$ (nonupwelling; Fig. 6), suggesting that N-loss and thus production of biogenic $\mathrm{N}_{2}$ are stimulated during upwelling in the Cariaco Basin. The upwelling period usually is associated with higher fluxes of settling particulate organic matter (Montes et al., 2012; Thunell et al., 2007). Enhanced vertical transport of particulate organic matter can be an important mode of supply of fixed nitrogen to the oxic-anoxic interface, where degradation of the flux releases ammonium and organic carbon that can be utilized by microbes. This is consistent with findings by Fuchsman et al. (2008) in the Black Sea, who observed higher production of biogenic $\mathrm{N}_{2}$ in years that had large phytoplankton blooms compared to those in which phytoplankton abundances were lower. Nutrient and suspended organic particle measurements from the CARIACO Ocean Time Series program show that DIN, POC and particulate organic nitrogen (PON) at the oxic-anoxic interface $(\sim 250 \mathrm{~m})$ were higher in March 2009 than in September 2008 (5.18 vs. $1.02 \mu \mathrm{mol} \mathrm{N} \mathrm{kg}{ }^{-1}, 65.12$ vs. $46.04 \mu \mathrm{g} \mathrm{C} \mathrm{kg}^{-1}$ and 11.16 vs. $8.05 \mu \mathrm{g} \mathrm{N} \mathrm{kg}^{-1}$, respectively). Furthermore, particulate settling flux records from CARIACO show that mean PON fluxes (1997-2010) at $\sim 400 \mathrm{~m}$ tend to be higher in March than in September months (Fig. 7); mean PON fluxes for CARIACO were used since settling flux data were not available for 2009 because of a mooring malfunction. These observations suggest that more inorganic and organic forms of dissolved nitrogen are available during upwelling compared to non-upwelling periods, stimulating N-loss processes during upwelling.

Ammonium produced by the decay of sinking organic matter, in particular, is likely an important DIN source for $\mathrm{N}$ loss. It can be incorporated into non-canonical nitrogen pathways such as coupled nitrification-denitrification in which nitrifiers exploit the newly generated ammonium at the oxicanoxic interface, producing nitrite and nitrate that can, in turn, be utilized by heterotrophic denitrifiers. Another plausible utilization pathway of $\mathrm{NH}_{4}^{+}$is anammox. Historical nutrient records from the CARIACO Time Series program indicate that $\mathrm{NO}_{2}^{-}$is occasionally present at the interface in high enough concentrations to fuel the anammox reaction (Scranton et al., 2006). Wakeham et al. (2012) also shows extensive evidence for anammox taking place at the oxic-anoxic inter-

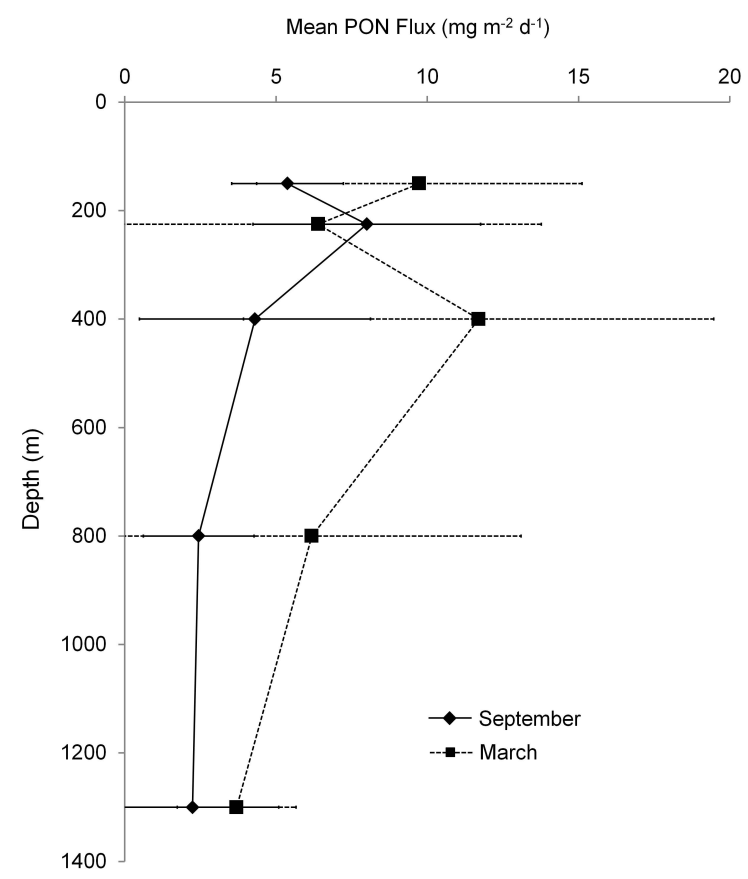

Fig. 7. Mean vertical PON flux during September (non-upwelling) and March (upwelling) months from the CARIACO Ocean Time Series between 1997 and 2010.

face in Cariaco. They found that anammox bacteria and ladderane lipids, an anammox bacterial biomarker, were abundant at $\sim 250 \mathrm{~m}$. Furthermore, maxima in chemoautotrophic production rates (dark DIC assimilation) have also been measured at this depth, likely as a result of the presence of the anammox metabolism and perhaps autotrophic denitrification (or thiodenitrification) within this layer (Taylor et al., 2001, 2006; Wakeham et al., 2012).

From the observations reported in this study, however, we cannot determine which specific pathways (denitrification or anammox) dominate the conversion of DIN to biogenic $\mathrm{N}_{2}$ within Cariaco's sub-oxic layer. Nonetheless, from a general perspective our results shed light on the microbially mediated biogeochemical processes that impact the production of biogenic $\mathrm{N}_{2}$ in the basin on a seasonal basis. Here we propose a model explaining the response of the $\mathrm{N}$-loss to the upwelling cycle of Cariaco. The rain of organic matter is an important source of carbon and nitrogen for autotrophs and heterotrophs at the oxic-anoxic interface. Previous work has shown that seasonal changes in bacterial respiration rates within this layer can be associated with changes in the upwelling conditions in the basin (Taylor et al., 2006, 2009). Our hypothesis is that enhanced settling flux of organic matter during the upwelling period stimulates both heterotrophic and autotrophic metabolism at the oxic-anoxic interface. Though in a different setting, Lomas et al. (2010) found that Sargasso Sea's mesopelagic export production $(300 \mathrm{~m})$ has remained constant since the late 90's, while epipelagic export 
$(\sim 150 \mathrm{~m})$ has increased. They suggested that the decrease in the POC transfer efficiency (POC flux at $300 \mathrm{~m}$ : POC flux at $150 \mathrm{~m}$ ) is the result of enhanced microbial respiration rates. In other words, heterotrophy responds proportionally to the increase in the POC flux below the euphotic zone. Enhanced microbial metabolism, such as denitrification and anammox within the oxic-anoxic layer in Cariaco would thus result in higher biogenic $\mathrm{N}_{2}$ production during the upwelling period. During the relaxation period, however, when the flux of organic matter escaping the base of the euphotic zone is lower (Montes et al., 2012), a decrease of the microbial activity can be expected, which would lead to lower production of biogenic $\mathrm{N}_{2}$.

An alternative explanation for the increase in biogenic $\mathrm{N}_{2}$ is water mass intrusions at intermediate depths. Episodic intrusions of oxygen and nutrient-rich water masses from the Caribbean Sea deepen the oxic-anoxic interface in the Cariaco Basin (Astor et al., 2003). These alter the vertical distribution of redox sensitive species such as hydrogen sulfide, iron and manganese oxides, and ammonium, among others (Percy et al., 2008; Scranton et al., 2001, 2006). Dissolved oxygen concentrations were higher between the $\sim 25$ and $\sim 26$ isopycnal surfaces in March 2009 compared to September 2008 (Fig. 2). The increase in dissolved $\mathrm{O}_{2}$ during the upwelling season must result from enhanced vertical mixing and ventilation of cold $\left(\sim 21-22^{\circ} \mathrm{C}\right)$ subsurface waters. Higher $\left[\mathrm{O}_{2}\right]$ in the upper $\sim 120 \mathrm{~m}$ in March 2009 suggests that an intrusion of water from the Caribbean Sea could have occurred during the upwelling period. The supply of oxygen to the redoxcline would stimulate nitrification, and enhance the abundance of $\mathrm{NO}_{\mathrm{x}}$ available for denitrifiers. Though an increase in oxygen concentrations at this depth after an intrusion would inhibit denitrification, previous work has shown that oxygen is quickly consumed and that low oxygen conditions are restored within weeks at this depth (Scranton et al., 2006). The intrusion of nitrate-rich waters from the Caribbean would also stimulate denitrification at the oxicanoxic interface.

\subsection{DIN deficit and $\mathrm{N}_{2}^{\mathrm{xS}}$}

We estimate the DIN deficit $\left(\mathrm{N}_{\mathrm{def}}\right)$ in the basin as the amount of fixed nitrogen that has been removed by the N-loss (Chang et al., 2010; Devol et al., 2006). The $\mathrm{N}_{\text {def }}$ is calculated by subtracting the observed DIN $\left(\mathrm{N}_{\mathrm{obs}}\right)$ from the total expected fixed nitrogen $\left(\mathrm{N}_{\exp }=\left[\mathrm{NO}_{3}^{-}\right]+\left[\mathrm{NO}_{2}^{-}\right]+\left[\mathrm{NH}_{4}^{+}\right]\right)$based on in situ SRP concentrations and Redfield stoichiometry. DIN deficits within the anoxic portion of the water column in Cariaco are not likely affected by reduced metals adsorption. Unpublished data show that despite labile and oxideassociated particulate $P$ peak at Cariaco's oxic-anoxic interface, indicating SRP scavenging by reduced metals, SRP concentrations at this depth appear to be minimally impacted by such reactions (C. Benitez-Nelson, personal communication, 2012). Particulate $P$ has nanomolar concentrations while SRP concentrations are in the micromolar range. The expected DIN abundance is typically obtained by plotting DIN versus SRP concentrations measured in waters with dissolved $\mathrm{O}_{2}>65 \mu \mathrm{mol} \mathrm{kg}^{-1}$ (Devol et al., 2006). For our work we used nutrient data collected at the CARIACO Station and BATS during 2008 and 2009 using the same criteria as Devol et al. (Fig. 8). Data from the BATS program was used in this analysis since waters entering into the Cariaco Basin originate in the subtropical North Atlantic. $\mathrm{N}_{\exp }$ is then calculated by linear regression:

$\mathrm{N}_{\exp }=14.5\left(\mathrm{P}_{\mathrm{obs}}\right)-0.7$,

where $\mathrm{P}_{\mathrm{obs}}$ corresponds to in situ SRP concentrations. The negative Y-intercept indicates a DIN deficit when the SRP concentration is zero. The slope and intercept of 14.5 and 0.7 , respectively, are the result of averaging the corresponding values from the DIN : SRP relationships from the CARIACO Time Series $(13.8,0.5)$ and BATS $(15.1,0.9)$. These $\mathrm{N}$ : P relationships are similar to those reported from the eastern tropical South Pacific (15.8) and the Arabian Sea (14.9) (Chang et al., 2010, and Codispoti et al., 2001, respectively). The DIN deficit is then

$\mathrm{N}_{\mathrm{def}}=\left(\mathrm{N}_{\mathrm{exp}}-\mathrm{N}_{\mathrm{obs}}\right)$.

We based $\mathrm{N}_{\text {def }}$ estimates on monthly observations at the CARIACO Station (station 10 in this study) for 2008-2009 since no nitrite or SRP measurements were made at depths below $100 \mathrm{~m}$ during our cruises. We believe that these are representative for the basin because the vertical nutrient profiles within each season were similar among all stations during the regional cruises at the oxic-anoxic interface (Table 2).

DIN deficits in September 2008 and March 2009 were calculated by averaging the $\mathrm{N}_{\text {def }}$ for the CARIACO observations between August and October 2008, and between February and April 2009, respectively. Combined $\mathrm{N}_{\mathrm{def}}$ in the upper $\sim 120 \mathrm{~m}$ were below detection during both seasons, as expected, but increased in waters with low oxygen $(\geq 200 \mathrm{~m})$. Measurements of $\left[\mathrm{N}_{2}^{\mathrm{xS}}\right]$ were similar to $\mathrm{N}_{\mathrm{def}}$ (least squares linear correlation, $R^{2}=0.95, p<0.001$; Fig. 9), showing that biogenic $\mathrm{N}_{2}$ production reflects the amount of fixed nitrogen removed by the $\mathrm{N}$-loss process in Cariaco. Biogenic $\left[\mathrm{N}_{2}^{\mathrm{xS}}\right]$ tended to be slightly lower than $\mathrm{N}_{\text {def }}$ estimates (Fig. 9), likely due to the accumulation of SRP within the anoxic layer, which artificially amplifies $\mathrm{N}_{\text {def }}$ values.

These observations support the conclusion of Chang et al. (2010) that measurements of $\mathrm{N}_{2}^{\mathrm{xs}}$ provide a useful means for estimating $\mathrm{N}$-loss rates in oxygen minimum zones, and that $\mathrm{N}_{2}^{\mathrm{xs}}$ concentrations can be used to validate $\mathrm{N}$-loss rates in marine systems (see DeVries et al., 2012) where DIN deficits or $\mathrm{N}^{*}$ estimates are affected by non-Redfield $\mathrm{N}: \mathrm{P}$ ratios. Some potential problems of using DIN deficits calculated from SRP include variable $\mathrm{N}$ : $\mathrm{P}$ ratios, the scavenging of SRP by redox species such as iron and manganese oxides, or (specifically for Cariaco) the accumulation of SRP 


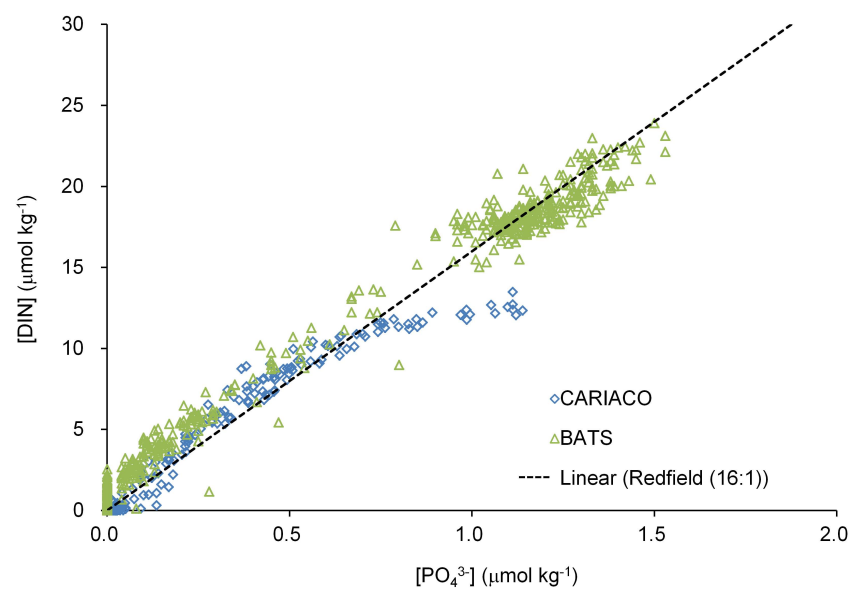

Fig. 8. Phosphate (SRP) versus DIN concentrations in waters with dissolved $\mathrm{O}_{2}$ concentrations above $\sim 65 \mu \mathrm{mol} \mathrm{kg} \mathrm{kg}^{-1}$ from the CARIACO Time Series and BATS during 2008 and 2009.

and ammonium below the oxic-anoxic interface (Scranton et al., 2006; Zhang and Millero, 1993). The excellent agreement between $\left[\mathrm{N}_{2}^{\mathrm{xs}}\right]$ and $\mathrm{N}_{\text {def }}$ supports our assertion that $\mathrm{N}_{2}^{\mathrm{xS}}$ in the Cariaco Basin is mainly of biological origin.

\section{Conclusions}

In this study we evaluated changes in $\mathrm{N}_{2}^{\mathrm{xs}}$ in the Cariaco Basin under contrasting seasonal conditions (upwelling versus non-upwelling). $\left[\mathrm{N}_{2}^{\mathrm{xS}}\right]$ were below detection at the surface, and increased to a mean value of $\sim 22 \mu \mathrm{mol} \mathrm{N} \mathrm{kg}{ }^{-1}$ at the oxic-anoxic interface $(250-300 \mathrm{~m})$ and deeper. Our $\left[\mathrm{N}_{2}^{\mathrm{xs}}\right]$ estimates are $\sim 25 \%$ larger than those from Richards and Benson (1961), suggesting that biogenic $\mathrm{N}_{2}$ has been accumulating in the basin at a rate of $\sim 0.08 \mu \mathrm{mol} \mathrm{N} \mathrm{kg} \mathrm{yr}^{-1}$.

$\left[\mathrm{N}_{2}^{\mathrm{xs}}\right.$ ] was higher by $\sim 3-6 \mu \mathrm{mol} \mathrm{N} \mathrm{kg}{ }^{-1}$ at $300-400 \mathrm{~m}$ during the upwelling period (March 2009) than when the basin was more thermally stratified (September 2008). Higher biogenic $\mathrm{N}_{2}$ production can be the result of enhanced DIN availability in Cariaco's oxic-anoxic interface during the upwelling period due to higher vertical transport of organic matter.

$\mathrm{N}$-loss at the oxic-anoxic interface of the Cariaco Basin appears to be stimulated during the upwelling period. We attribute this observation to two mechanisms: (1) increased supply of sinking organic nitrogen and/or (2) ventilation of the oxic-anoxic interface by intermediate oxygenated and nitrate-rich Caribbean waters.

DIN deficits based on nutrient Redfield stoichiometry within sub-oxic and anoxic waters in Cariaco are similar to our estimates of $\left[\mathrm{N}_{2}^{\mathrm{xs}}\right]$ at the corresponding depths. This suggests that $\mathrm{N}_{2}^{\mathrm{xs}}$ in Cariaco is generated mainly by biological processes associated with oceanic $\mathrm{N}$-loss.

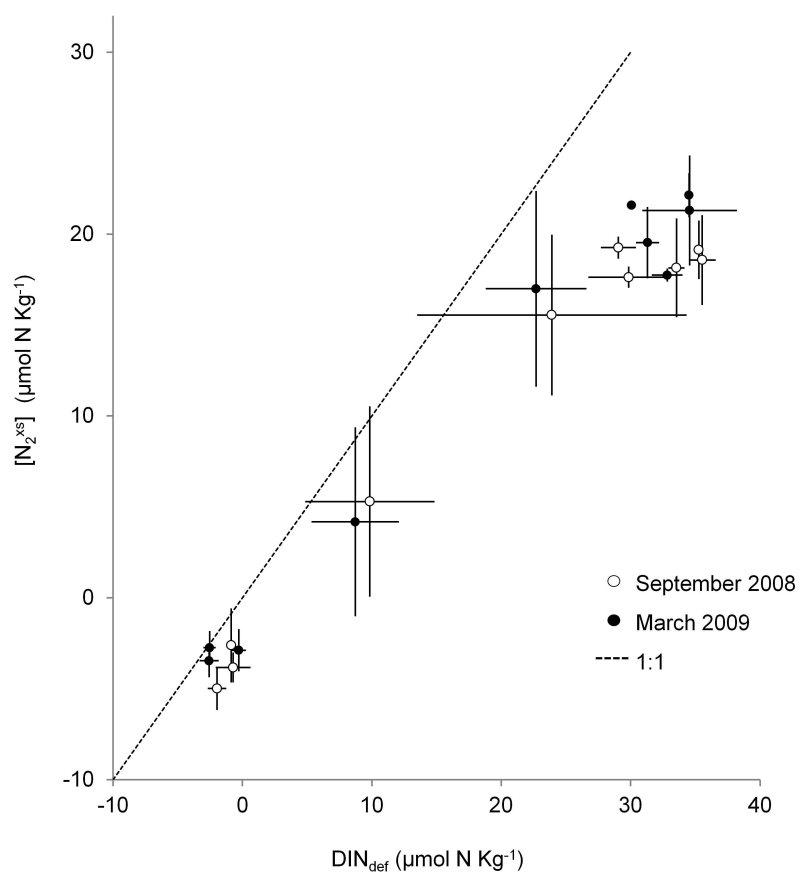

Fig. 9. Average DIN deficits $\left(\mathrm{DIN}_{\mathrm{def}}\right)$ versus $\left[\mathrm{N}_{2}^{\mathrm{Xs}}\right]$ (measured minus background $\mathrm{N}_{2}^{\mathrm{XS}}$ ) in the Cariaco Basin. The dashed line shows the theoretical $1: 1$ relationship.

Our observations show that measuring $\mathrm{N}_{2}^{\mathrm{xs}}$ is a robust method for quantifying the sink of fixed nitrogen in Cariaco and in low oxygen environments in general. We conclude that biogenic $\mathrm{N}_{2}$ determinations are a useful tool for complementing information provided by the $\mathrm{N}^{*}$ parameter, and should be considered in future studies addressing questions regarding the state of the contemporary global nitrogen cycle.

Acknowledgements. This work was supported by the CARIACO Ocean Time Series Project, funded by the National Science Foundation (Award \# OCE-0326268 and OCE-0963028) and the Fondo National de Investigaciones Científicas y Tecnológicas (FONACIT, Venezuela, Awards \# 96280221 and 2000001702). We deeply thank the Fundación La Salle de Ciencias Naturales, Estación de Investigaciones Marinas Isla Margarita (FLASA/EDIMAR) for their continuous effort in making this time series possible. We are grateful to Ana Herrera (Instituto de Biología Experimental, Universidad Central de Venezuela) for providing laboratory equipment and logistics for this study. We are especially indebted to the crew of the R/V Hermano Ginés (FLASA) for their able support at sea. We also thank two anonymous reviewers for their helpful comments. This is the Institute of Marine Remote Sensing (IMaRS) contribution \# 148.

Edited by: S. W. A. Naqvi 


\section{References}

Altabet, M. A., Higginson, M. J., and Murray, D. W.: The effect of millennial-scale changes in Arabian Sea denitrification on atmospheric $\mathrm{CO}_{2}$, Nature, 415, 159-162, 2002.

Astor, Y., Muller-Karger, F., and Scranton, M. I.: Seasonal and interannual variation in the hydrography of the Cariaco Basin: implications for basin ventilation, Cont. Shelf Res., 23, 125-144, 2003.

Benson, B. B. and Parker, P. D. M.: Nitrogen/argon and nitrogen isotope ratios in aerobic sea water, Deep-Sea Res., 7, 237-253, 1961.

Brandes, J. A. and Devol, A. H.: A global marine-fixed nitrogen isotopic budget: implications for Holocene nitrogen cycling, Global Biogeochem. Cy., 16, 1120, doi:10.1029/2001GB001856, 2002.

Brettar, I. and Rheinheimer, G.: Influence of carbon availability on denitrification in the central Baltic Sea, Limnol. Oceanogr. 37, 1146-1163, 1992.

Capone, D. G. and Knapp, A. N.: Oceanography: A marine nitrogen cycle fix?, Nature, 445, 159-160, 2007.

Chang, B. X., Devol, A. H., and Emerson, S. R.: Denitrification and the nitrogen gas excess in the eastern tropical South Pacific oxygen deficient zone, Deep-Sea Res. I, 57, 1092-1101, 2010.

Codispoti, L. A.: Phosphorus vs. nitrogen limitation of new and export production, in: Productivity of the Ocean: Present and Past, edited by: Berger, W. H., Smetacek, V. S., and Wefer, G., John Wiley \& Sons Limited, New York, 377-394, 1989.

Codispoti, L. A.: An oceanic fixed nitrogen sink exceeding $400 \mathrm{Tg}$ $\mathrm{N} \mathrm{a}^{-1}$ vs the concept of homeostasis in the fixed-nitrogen inventory. Biogeosciences 4, 233-253, 2007.

Codispoti, L. A., Brandes, J. A., Christensen, J. P., Devol, A. H., Naqvi, S. W. A., Paerl, H. W., and Yoshinari, T.: The oceanic fixed nitrogen and nitrous oxide budgets: Moving targets as we enter the anthropocene?, Sci. Mar., 65, 85-105, 2001.

Dalsgaard, T., Thamdrup, B., Farías, L., and Revsbech, N. P.: Anammox and denitrification in the oxygen minimum zone of the eastern South Pacific, Limnol. Oceanogr., 57, 1331-1346, doi:10.4319/lo.2012.57.5.1331, 2012.

Deutsch, C., Sarmiento, J. L., Sigman, D. M., Gruber, N., and Dunne, J. P.: Spatial coupling of nitrogen inputs and losses in the ocean, Nature, 445, 163-167, 2007.

Devol, A., Uhlenhopp, A., Naqvi, S., Brandes, J., Jayakumar, D., Naik, H., Gaurin, S., Codispoti, L., and Yoshinari, T.: Denitrification rates and excess nitrogen gas concentrations in the Arabian Sea oxygen deficient zone, Deep-Sea Res. I, 53, 1533-1547, 2006.

DeVries, T., Deutsch, C., Primeau, F., Chang, B., and Devol, A.: Global rates of water-column denitrification derived from nitrogen gas measurements, Nat. Geosci., 5, 547-550, 2012.

Falkowski, P. G.: Evolution of the nitrogen cycle and its influence on the biological sequestration of $\mathrm{CO}_{2}$ in the ocean, Nature, 387 , 272-275, 1997.

Falkowski, P. and Kiefer, D. A.: Chlorophyll $a$ fluorescence in phytoplankton: relationship to photosynthesis and biomass, J. Plankton Res. 7, 715-731, 1985.

Fuchsman, C. A., Murray, J. W., and Konovalov, S. K.: Concentration and natural stable isotope profiles of nitrogen species in the Black Sea, Mar. Chem., 111, 90-105, 2008.
Fuchsman, C. A., Murray, J. W., and Staley, J. T.: Stimulation of autotrophic denitrification by intrusions of the Bosporus Plume into the anoxic Black Sea, Front. Microbiol., 3, 257, doi:10.3389/fmicb.2012.00257, 2012.

Ganeshram, R. S., Pedersen, T. F., Calvert, S. E., McNeill, G. W., and Fontugne, M. R.: Glacialinterglacial variability in denitrification in the World's oceans: causes and consequences, Paleoceanography, 15, 361-376, 2000.

Gordon, L. I., Jennings, J. C., Ross, A. A., and Krest, J. M.: Suggested protocol for continuous flow automated analysis of seawater nutrients, WOCE Operation Manual, WHP Office Rept 90-1, WOCE Rept 77 No 68/91, 1-52, 2000.

Gruber, N.: The dynamics of the marine nitrogen cycle and its influence on atmospheric $\mathrm{CO}_{2}$, in: The Ocean Carbon Cycle and Climate, edited by: Follows, M. and Oguz, T., Kluwer Academic Publishers, Dordrecht, Netherlands, 97-148, 2004.

Gruber, N. and Sarmiento, J. L.: Global patterns of marine nitrogen fixation and denitrification, Global Biogeochem. Cy., 11, 235266, 1997.

Gruber, N. and Sarmiento, J. L.: Biogeochemical/physical interactions in elemental cycles, in: THE SEA: Biological-Physical Interactions in the Oceans, edited by: Robinson, A. R., McCarthy, J. J., and Rothschild, B. J., John Wiley and Sons, New York, 337399, 2002.

Hamme, R. C. and Emerson, S. R.: Mechanisms controlling the global oceanic distribution of the inert gases argon, nitrogen and neon, Geophys. Res. Lett., 29, 2120, doi:10.1029/2002GL015273, 2002.

Hamme, R. and Emerson, S.: The solubility of neon, nitrogen and argon in distilled water and seawater, Deep-Sea Res. Pt. I, 51, 1517-1528, 2004.

Hamme, R. C. and Severinghaus, J. P.: Trace gas disequilibria during deep-water formation, Deep-Sea Res. I, 54, 939-950, 2007.

Holm-Hansen, O., Lorenzen, C. J., Holmes, R. W., and Strickland, J. D. H.: Fluorometric determination of chlorophyll, J. Conseil, 30, 3-15, 1965.

Holmén, K. J. and Rooth, C. G. H.: Ventilation of the Cariaco Trench, a case of multiple source competition?, Deep-Sea Res. Pt. I, 37, 203-225, 1990.

Jensen, M. M., Petersen, J., Dalsgaard, T., and Thamdrup, B.: Pathways, rates and regulation of $\mathrm{N}_{2}$ production in the chemocline of an anoxic basin, Mariager Fjord, Denmark, Mar. Chem., 113, 102-113, 2009.

Li, X., Taylor, G. T., Astor, Y., and Scranton, M. I.: Relationship of sulfur speciation to hydrographic conditions and chemoautotrophic production in the Cariaco Basin, Mar. Chem., 112, 5364, 2008.

Li, X., Cutter, G. A., Thunell, R. C., Tappa, E., Gilhooly Iii, W. P., Lyons, T.W ., Astor, Y., Scranton, M. I.: Particulate sulfur species in the water column of the Cariaco Basin, Geochim. Cosmochim. Ac., 75, 148-163, 2011.

Lidz, L., Charm, W. B., Ball, M. M., and Valdes, S.: Marine Basins off the coast of Venezuela, B. Mar Sci., 19, 1-17, 1969.

Liu, K.-K. and Kaplan, I. R.: Denitrification rates and availability of organic matter in marine environments, Earth Planet. Sc. Lett., 68, 88-100, 1984.

Löffler, A., Schneider, B., Schmidt, M., and Nausch, G.: Estimation of denitrification in Baltic Sea deep water from gas tension measurements, Mar. Chem., 125, 91-100, 2011. 
Lomas, M. W., Steinberg, D. K., Dickey, T., Carlson, C. A., Nelson, N. B., Condon, R. H., and Bates, N. R.: Increased ocean carbon export in the Sargasso Sea linked to climate variability is countered by its enhanced mesopelagic attenuation, Biogeosciences, 7, 57-70, doi:10.5194/bg-7-57-2010, 2010.

Montes, E., Muller-Karger, F., Thunell, R., Hollander, D., Astor, Y., Varela, R., Soto, I., and Lorenzoni, L.: Vertical fluxes of particulate biogenic material through the euphotic and twilight zones in the Cariaco Basin, Venezuela, Deep-Sea Res. I, 67, 73-84, 2012.

Muller-Karger, F., Varela, R., Thunell, R., Scranton, M., Bohrer, R., Taylor, G., Capelo, J., Astor, Y., Tappa, E., Ho, T.-Y., and Walsh, J. J.: Annual cycle of primary production in the Cariaco Basin: Response to upwelling and implications for vertical export, J. Geophys. Res., 106, 4527-4542, 2001.

Muller-Karger, F. E., Varela, R., Thunell, R. C., Scranton, M. I., Taylor, G. T., Astor, Y., Benitez-Nelson, C. R., Lorenzoni, L., Tappa, E., Goñi, M. A., Rueda, D., and Hu, C.: The CARIACO oceanographic time series, in: Carbon and Nutrient Fluxes in Continental Margins: a Global Synthesis, JGOFS Continental Margins Task Team (CMTT), edited by: Liu, K.-K., Atkinson, L., Quinones, R., and Talaue-McManus, L., Springer-Verlag, Berlin Heidelberg, 454, 2010.

Nicholson, D., Emerson, S., Caillon, N., Jouzel, J., Hamme, R. C.: Constraining ventilation during deepwater formation using deep ocean measurements of the dissolved gas ratios ${ }^{40} \mathrm{Ar} /{ }^{36} \mathrm{Ar}, \mathrm{N}_{2} / \mathrm{Ar}$, and $\mathrm{Kr} / \mathrm{Ar}$, J. Geophys. Res., 115, C11015, doi:10.1029/2010JC006152, 2010.

Percy, D., Li, X., Taylor, G. T., Astor, Y., and Scranton, M. I.: Controls on iron, manganese and intermediate oxidation state sulfur compounds in the Cariaco Basin, Mar. Chem., 111, 47-62, 2008.

Richards, F. A.: The Cariaco Basin (Trench), Oceanogr. Mar. Biol., 13, 11-67, 1975.

Richards, F. A. and Benson, B. B.: Nitrogen/argon and nitrogen isotope ratios in two anaerobic environments, the Cariaco Trench in the Caribbean Sea and Dramsfjord, Norway, Deep-Sea Res., 7, 254-264, 1961.

Schubert, C.: Origin of Cariaco Basin, southern Caribbean Sea, Mar. Geol., 47, 345-360, 1982.

Scranton, M. I., Astor, Y., Bohrer, R., Ho, T.-Y., and Muller-Karger, F.: Controls on temporal variability of the geochemistry of the deep Cariaco Basin, Deep-Sea Res. Pt. I, 7, 1605-1625, 2001.
Scranton, M. I., McIntyre, M., Astor, Y., Taylor, G. T., MüllerKarger, F., and Fanning, K.: Temporal variability in the nutrient chemistry of the Cariaco Basin, in: Past and Present Water Column Anoxia, edited by: Neretin, L. N., Springer Netherlands, 139-160, 2006.

Smith, S. V.: Phosphorus versus nitrogen limitation in the marine environment, Limnol. Oceanogr., 29, 1149-1160, 1984.

Strickland, J. D. H. and Parsons, T. R.: A practical handbook of seawater analysis, Fisheries Research Board of Canada, Ottawa, Ontario, 1972.

Taylor, G. T., Iabichella, M., Ho, T.-Y., Scranton, M. I., Thunell, R. C., Müller-Karger, F., and Varela, R.: Chemoautotrophy in the redox transition zone of the Cariaco Basin: A significant midwater source of organic carbon production, Limnol. Oceanog., 46, 148-163, 2001.

Taylor, G. T., Labichella-Armas, M., Varela, R., Müller-Karger, F., Lin, X., and Scranton, M. I.: Microbial Ecology of the Cariaco Basin's oxic-anoxic interface: the U.S.-Venezuela CARIACO Times Series Program, in: Past and Present Water Column Anoxia, NATO Science Series, edited by: Neretin, L. N., Springer, Netherlands, 473-499, 2006.

Taylor, G. T., Thunell, R., Varela, R., Benitez-Nelson, C., and Scranton, M. I.: Hydrolytic ectoenzyme activity associated with suspended and sinking organic particles within the anoxic Cariaco Basin, Deep-Sea Res. I, 56, 1266-1283, doi:10.1016/j.dsr.2009.02.006, 2009.

Thunell, R., Benitez-Nelson, C., Varela, R., Astor, Y., and MullerKarger, F.: Particulate organic carbon fluxes along upwellingdominated continental margins: Rates and mechanisms, Global Biogeochem. Cy., 21, GB1022, doi:10.1029/2006GB002793, 2007.

Wakeham, S. G., Turich, C., Schubotz, F., Podlaska, A., Li, X. N., Varela, R., Astor, Y., Sáenz, J. P., Rush, D., Sinninghe Damsté, J. S., Summons, R. E., Scranton, M. I., Taylor, G. T., and Hinrichs, K.-U.: Biomarkers, chemistry and microbiology show chemoautotrophy in a multilayer chemocline in the Cariaco Basin, Deep Sea Res. I, 63, 133-156, 2012.

Ward, B. B., Tuit, C. B., Jayakumar, A., Rich, J. J., Moffett, J., and Naqvi, S. W. A.: Organic carbon, and not copper, controls denitrification in oxygen minimum zones of the ocean, Deep-Sea Res. I, 55, 1672-1683, 2008.

Zhang, J.-Z. and Millero, F. J.: The chemistry of the anoxic waters in the Cariaco Trench, Deep-Sea Res. I, 40, 1023-1041, 1993. 